\title{
Epidemiological, clinical and immunohistochemical aspects of canine lymphoma in the region of Porto Alegre, Brazil ${ }^{1}$
}

\author{
Elisa B. Neuwald², Luciele V. Teixeira², Francisco O. Conrado ${ }^{3}$, Mariana O.D. da \\ Silva $^{4}$, Nicole R.C. Hlavac ${ }^{2}$ e Félix H.D. González ${ }^{5}$
}

\begin{abstract}
Neuwald E.B., Teixeira L.V., Conrado F.O, Silva M.O.D., Hlavac N.R.C. \& González F.H.D. 2014. Epidemiological, clinical and immunohistochemical aspects of canine lymphoma in the region of Porto Alegre, Brazil. Pesquisa Veterinária Brasileira 34(4):349-354. Programa de Pós-Graduação em Ciências Veterinárias, Universidade Federal do Rio Grande do Sul, Av. Bento Gonçalves 9090, Porto Alegre, RS 91540-000, Brazil. E-mail: eneuwald@ibest.com.br

This paper describes the epidemiological, clinical and immunohistochemical characteristics of canine lymphomas diagnosed in the region of Porto Alegre, Brazil. Thirty dogs were enrolled in the study; most of them were male (60\%), mixed-breed (23\%) and middle-aged or older. The majority (87\%) of affected dogs showed the multicentric form. The B-cell phenotype was most frequently detected (62\%); $37 \%$ of the animals were in clinical stage IV, and $83 \%$ were classified as sub-stage "b". Lymphadenopathy was observed in $67 \%$ of the cases, and dyspnea, prostration, decreased appetite and vomiting were the most common clinical signs encountered. Anemia was a frequently encountered laboratory alteration (57\%), as were leukocytosis (40\%), thrombocytopenia (33\%), lymphopenia (30\%), hyperglobulinemia (20\%) and hypercalcemia (13\%). The results of this study indicate that the clinical features of dogs with lymphoma in the region of Porto Alegre are similar to those observed worldwide.
\end{abstract}

INDEX TERMS: Lymphoma, paraneoplastic syndromes, clinical signs, immunohistochemistry, dogs.

RESUMO.- [Aspectos epidemiológicos, clínicos e imuno-histoquímicos do linfoma canino na região de Porto Alegre.] Esse trabalho apresenta os achados epidemiológicos, clínicos e imuno-histoquímicos de linfomas caninos diagnosticados na região de Porto Alegre. Trinta cães foram incluídos no estudo; sendo principalmente machos (60\%), sem raça definida (23\%) e de meia-idade a idosos. A maioria (87\%) dos cães afetados apresentou a forma anatômica multicêntrica. $\mathrm{O}$ imunofenótipo B foi detectado com mais frequência (62\%); 37\% dos cães apresentavam

\footnotetext{
${ }^{1}$ Received on August 22, 2013.

Accepted for publication on March 5, 2014.

${ }^{2}$ Programa de Pós-Graduação em Ciências Veterinárias, Universidade Federal do Rio Grande do Sul (UFRGS), Av. Bento Gonçalves 9090, Porto Alegre, RS 91540-000, Brazil. * Corresponding author: eneuwald@ibest.com.br

${ }^{3}$ Programa de Pós-Graduação em Ciências Veterinárias da Universidade Federal do Paraná (UFPR), Rua dos Funcionários 1540, Curitiba, PR 80035-050, Brazil.

${ }^{4}$ Faculdade de Medicina Veterinária (Favet), UFRGS, Av. Bento Gonçalves 9090, Porto Alegre, RS 91540-000.

${ }^{5}$ Departamento de Patologia Clínica Veterinária, Favet-UFRGS, Porto Alegre, RS.
}

estadiamento clínico IV e 83\% encontravam-se no subestádio "b". Linfadenopatia foi observada em $67 \%$ dos casos; outros sinais clínicos comumente detectados foram dispneia, prostração, diminuição do apetite e vômitos. Anemia foi a alteração laboratorial mais frequente (57\%), seguida por leucocitose (40\%), trombocitopenia (33\%), linfopenia (30\%), hiperglobulinemia (20\%), hiperproteinemia (17\%) e hipercalcemia (13\%). Os resultados do presente estudo indicam que as características epidemiológicas e clínicas de cães com linfoma na região de Porto Alegre são semelhantes às observadas em todo o mundo.

TERMOS DE INDEXAÇÃO: Linfoma, síndromes paraneoplásicas, sinais clínicos, imuno-histoquímica, caninos.

\section{INTRODUCTION}

Lymphoma is the most common canine hematopoietic neoplasm, with reported incidences of 24 to 33 cases per 100,000 dogs (Dorn et al. 1967, Teske 1994). In Brazil, lymphoma is the second most common canine neoplasm leading to death or euthanasia (Fighera et al. 2008). Although in recent years considerable advances have been made in 
the treatment of canine lymphoma, it is important to establish a standard diagnostic approach to properly identify the disease and to formulate a correct prognosis and adequate therapeutic protocol (Gavazza et al. 2008).

According to the World Health Organization, canine lymphomas can be classified into five clinical stages and two sub-stages, reflecting the degree of involvement of affected organs and the clinical signs presented by the animal, respectively (Vail \& Young 2007). Thus, the extent of the disease can be described, and most canine lymphomas are presented in advanced stage of disease, III, IV or $\mathrm{V}$ (Teske 1994). The clinical signs associated with lymphoma in dogs are variable, depending among other factors on the location of the tumour. The anatomic forms of canine lymphoma in order of occurrence are multicentric, mediastinal, alimentary, cutaneous and extranodal forms (Vail \& Yong 2007). In the multicentric form a generalized painless lymphadenopathy is the most consistent find; hepatosplenomegaly and bone marrow involvement occur frequently. Other non-specific clinical signs include depression, emaciation, anorexia, vomiting, diarrhea, dyspnea and fever (Van Pelt \& Conner 1968). The mediastinal form is characterized by enlarged of the cranial mediastinal lymph nodes and/or thymus, and clinical signs include dyspnea, coughing, exercise intolerance and regurgitation (Teske 1994, Cardoso et al. 2003). The vena cava syndrome, which is characterized by edema of the face, neck and thoracic members, can occur in this form (Fighera et al. 2002). Dogs with the alimentary form of lymphoma usually present with non-specific gastrointestinal signs of vomiting, diarrhea and weight loss; mesenteric lymph nodes, liver and spleen may also been involved (Teske 1994, Fighera et al. 2002). Cutaneous lymphoma in the dog can be generalized or multifocal; and histologically they can be divided into epidermotropic (usually T-cell origin) and non-epidermotropic types (usually B-cell origin). Tumours occur as nodules, plaques, ulcers, erythoderma and exfoliative dermatitis (Vail \& Young 2007). The extranodal lymphoma is a rare form that can affect any corporal tissue, and the most common sites are ocular and neural lymphomas (Fighera et a. 2002, Cardoso et al. 2003).

Canine lymphomas also can be classified according to the morphology and the immunophenotype (Fournel-Fleury et al. 1997). The morphological canine classifications have been successively based on different human classifications, taking account of epidemiological, clinical, phenotypic and genetic features and identifying clinicomorphological entities (Ponce et al. 2010). Recognition that lymphoma cells derive from T or B cells is very important because the immunophenotype is also related to prognosis. Most canine lymphomas are type B (Fournel-Fleury et al. 1997, Vezzali et al. 2009, Ponce et al. 2010), and dogs with T-cell lymphomas exhibited a low complete response rate to chemotherapy as well as shortened remission and survival times (Greenlee et al. 1990). The clinical features of human lymphoma vary among different countries and regions; in the western world the majority of lymphomas are of B-cell origin and some 10-20\% are T-cell lymphomas, while in Asia T-cell lymphoma are more common (Fisher \&
Fisher 2004). It is possible that such variation also occurs in veterinary medicine.

Moreover, lymphoma can lead to paraneoplastic syndromes, which are the disorders of an organ function produced by the noninvasive actions of the tumor (Morrison 1979). The most frequent paraneoplastic syndromes of lymphoma in dogs include hypercalcemia, gammopathy, anemia, thrombocytopenia, leucocytosis and cachexia. These syndromes can affect the outcome of the patient and sometimes are the first sign of malignancy (Vail \& Young 2007).

The purpose of this study was to describe the epidemiological, clinical and immunohistochemical features of canine lymphomas diagnosed in the region of Porto Alegre, Rio Grande do Sul, Brazil.

\section{MATERIALS AND METHODS}

Thirty dogs were enrolled in the study. All dogs diagnosed with lymphoma cytologically or histologically between May of 2010 and May of 2012 at the veterinary clinical hospital of the Federal University of Rio Grande do Sul entered in the study. This study was approved by the ethical review committee (protocol number 18391-CEUA-UFRGS), and informed consent was obtained from each owner of the patient. Data from anamnesis was collected to evaluate the occurrence of clinical signs. All dogs underwent a physical examination and diagnostic work-up; whole blood was collected in $4 \mathrm{~mL}$ non-additive and in $3 \mathrm{~mL}$ EDTA tubes from cephalic and jugular veins. The exams performed included complete blood count (CBC) with differential and platelet count, serum biochemical analysis (albumin, alanine aminotransferase, aspartate aminotransferase, creatine phosphokinase, creatinine, alkaline phosphatase, glucose, fructosamine, total protein, urea, globulins, protein electrophoresis, calcium, and lactate dehydrogenase), and abdominal ultrasonography. A bone marrow evaluation was performed in 24 out of the 30 dogs. In three dogs, bone marrow examination was not possible due to repeated dry taps. In three other animals, this procedure was not authorized by the owners. Bone marrow aspirates were performed before starting chemotherapy. The animals were anesthetized (tramadol as preanesthetic and propofol for the induction and maintenance of anesthesia) and the aspiration was performed, preferably from the iliac crest or the proximal humerus.

The diagnosis of lymphoma was based on fine-needle biopsies and cytological examination of enlarged lymph nodes in 26 dogs and biopsy or citology of other affected organs (skin in 2 dogs, spleen in one and intestinal in one dog). In 23 dogs a lymph node sample was collected with a thick needle ( $40 \mathrm{~mm} \times 1.2 \mathrm{~mm}$ ) and in two dogs a skin sample was collected by the same way. In addition, a small intestine sample was collected from one dog. Immunohistochemistry was not performed in four animals: in three dogs because samples with a thick needle were not collected and in one dog because the spleen was involved and the owner therefore did not authorize the procedure. The tissue samples for immunohistochemistry were fixed in 10\% buffered formalin and embedded in paraffin wax. Phenotyping of lymphomas was performed with CD3 (DAKO Corp., Carpinteria, CA, Clone F7.2.38) antibodies to identify T-cells and PAX5 (DAKO Corp., Carpinteria, CA, Dak-PAX5) to identify B-cells. The endogenous peroxidase activity was inhibited by immersing the tissue sections in a 10\% hydrogen peroxide in methanol solution for 15 minutes. Antigen retrieval was performed in moist heat $\pm 90^{\circ} \mathrm{C}$ (Steam Cuisine 700 Hi Speed - T-Fal ${ }^{\circledR}$ ) for 20 minutes, followed by cooling at room temperature. Nonspecific reactions were blocked by immersion in skimmed milk 5\% (Molico ${ }^{\circledR}$ ) for 25 minutes. The monoclonal anti-human 
CD3 and PAX5 antibody were used at 1:300 e 1:1000, respectively, dilution in phosphate-buffered saline (PBS). Slices were overnight incubated with the primary antibody in a humid chamber. Next, the specimens were incubated with a standard avidin-biotin-immunoperoxidase (ABC Kit Horserardish Peroxidase - DAKO Copr., Carpinteria, CA). DAB (DAB Reagent Set KPL, Washington, DC) was the chromogen and Harris hematoxylin was used as the counterstain.

The anatomical form and the clinical stage of the cases were based on the results of physical examination and diagnostic work-up according to the World Health Organization (Owen 1980). The cutaneous form was classified as clinical stage V. Paraneoplastic syndromes were evaluated based on laboratory tests and physical examinations. The body condition of the dog was evaluated at the time of diagnosis and assigned a value on a scale of 1 to 5 (Kronfeld et al. 1991).

Descriptive statistics were used to describe population characteristics and the occurrence of clinical signs and laboratory abnormalities. The categorical data were expressed as frequencies and quantitative variables were expressed as the means and standard deviations or minimum and maximum values.

\section{RESULTS}

A total of 30 dogs - 18 males (60\%) and 12 females (40\%) - were diagnosed with lymphoma during the study period. Characteristics of these dogs are shown in Table 1. The mean age of the subjects was 9 years (range from 3 to 14 ) and the mean weight was $19.5 \mathrm{~kg}$ (range from 2 to $48 \mathrm{~kg}$ ). The majority of the animals were mixed breed $(\mathrm{n}=7-23.3 \%)$. Breeds represented included Poodle $(\mathrm{n}=5)$, Labrador Retriever $(\mathrm{n}=3)$, Boxer $(\mathrm{n}=2)$, Rottweiler $(\mathrm{n}=2)$, Bichon Frise ( $\mathrm{n}=2)$, Shih Tzu, Weimaraner, Saint Bernard, Brazilian Terrier, Bull Terrier, German Shepherd, Bulldog, Chow Chow and Scottish Terrier ( $\mathrm{n}=1$ each). Multicentric lymphoma was the most frequently encountered anatomical form, occurring in 26 dogs (87\%). Two dogs (7\%) were diagnosed with the cutaneous form one dog with the intestinal form (3\%) and one with the splenic form (3\%).

Bone marrow evaluation showed involvement in 5 cases, showing moderate to severe linfoblastic proliferation and atypical lymphocytes in the CBC. Immunohistochemical evaluation of samples showed that the majority of tumors were B phenotype lymphomas, occurring in 16 dogs (62\%). T-cell lymphoma occurred in 10 dogs (38\%). All B-cell immunophenotypes were multicentric lymphomas, and the T-cell types were multicentric (7), cutaneous (2) and intestinal (1).

One dog (3\%) was classified as being in stage I, 10 dogs (33\%) in stage III, 11 dogs (37\%) in stage IV and 8 dogs $(27 \%)$ in stage V. Five dogs were classified as being in sub-stage "a" (17\%) and 25 in sub-stage "b" (83\%). Lymphadenopathy was observed in $67 \%$ of the dogs. Other frequent clinical signs included dyspnea (36\%), prostration (32\%), decreased appetite (32\%), vomiting (32\%), emaciation (16\%), gagging (16\%), skin lesions $(8 \%)$, anorexia (8\%), diarrhea (8\%), polydipsia (4\%), cough (4\%) and increased

Table 1. Population characteristic of dogs with lymphoma diagnosed in Porto Alegre/RS, Brazil

\begin{tabular}{|c|c|c|c|c|c|c|c|c|}
\hline Number & Breed & $\begin{array}{c}\text { Age } \\
\text { (years) }\end{array}$ & $\begin{array}{c}\text { Weight } \\
\text { (kg) }\end{array}$ & Sex & Type & Stage & $\begin{array}{l}\text { Sub- } \\
\text { stage }\end{array}$ & $\begin{array}{l}\text { Immunohis- } \\
\text { tochemistry }\end{array}$ \\
\hline 1 & Mixed breed & 13 & 19.3 & Male & multicentric & V & $\mathrm{b}$ & B \\
\hline 2 & Mixed breed & 9 & 10.7 & Male & multicentric & IV & $\mathrm{b}$ & B \\
\hline 3 & Mixed breed & 7 & 11.4 & Male & multicentric & V & $\mathrm{b}$ & B \\
\hline 4 & Mixed breed & 8 & 8.5 & Female & multicentric & I & $\mathrm{b}$ & $\mathrm{T}$ \\
\hline 5 & Mixed breed & 7 & 10 & Male & multicentric & III & $\mathrm{b}$ & $\mathrm{T}$ \\
\hline 6 & Mixed breed & 8 & 11.3 & Male & cutaneous & V & $\mathrm{b}$ & $\mathrm{T}$ \\
\hline 7 & Mixed breed & 14 & 8.2 & Female & intestinal & V & $\mathrm{b}$ & $\mathrm{T}$ \\
\hline 8 & Poodle & 11 & 6 & Female & multicentric & III & $\mathrm{a}$ & B \\
\hline 9 & Poodle & 14 & 14 & Male & multicentric & V & b & B \\
\hline 10 & Poodle & 14 & 2 & Female & multicentric & III & $\mathrm{b}$ & $\mathrm{T}$ \\
\hline 11 & Poodle & 13 & 5 & Male & multicentric & IV & $\mathrm{b}$ & - \\
\hline 12 & Poodle & 7 & 12.3 & Female & cutaneous & V & $\mathrm{b}$ & $\mathrm{T}$ \\
\hline 13 & Labrador & 9 & 48 & Male & multicentric & III & $\mathrm{b}$ & B \\
\hline 14 & Labrador & 5 & 31 & Male & multicentric & IV & $\mathrm{b}$ & B \\
\hline 15 & Labrador & 12 & 35 & Female & multicentric & III & b & $\mathrm{T}$ \\
\hline 16 & Boxer & 6 & 25.7 & Female & multicentric & IV & $\mathrm{b}$ & $\mathrm{B}$ \\
\hline 17 & Boxer & 6 & 31.5 & Male & multicentric & III & $\mathrm{b}$ & - \\
\hline 18 & Rottweiler & 10 & 45 & Female & multicentric & III & $\mathrm{a}$ & B \\
\hline 19 & Rottweiler & 7 & 33.2 & Female & splenic & IV & $\mathrm{b}$ & - \\
\hline 20 & Bichon frise & 13 & 10 & Male & multicentric & V & $\mathrm{b}$ & $\mathrm{B}$ \\
\hline 21 & Bichon frise & 6 & 6.9 & Male & multicentric & IV & $\mathrm{b}$ & $\mathrm{T}$ \\
\hline 22 & Weimaraner & 9 & 36 & Male & multicentric & III & $\mathrm{b}$ & $\mathrm{T}$ \\
\hline 23 & Brazilian Terrier & 12 & 7.4 & Female & multicentric & IV & $\mathrm{a}$ & $\mathrm{B}$ \\
\hline 24 & Scottish terrier & 9 & 8.5 & Female & multicentric & IV & $\mathrm{a}$ & B \\
\hline 25 & Bullterrier & 3 & 23 & Male & multicentric & III & $\mathrm{b}$ & B \\
\hline 26 & Saint Bernard & 8 & 41.5 & Male & multicentric & IV & b & B \\
\hline 27 & Shih Tzu & 7 & 8 & Male & multicentric & IV & $\mathrm{b}$ & - \\
\hline 28 Ger & erman shepherd & 9 & 39 & Male & multicentric & III & $\mathrm{a}$ & $\mathrm{B}$ \\
\hline 29 & Bulldog & 3 & 20 & Female & multicentric & IV & $\mathrm{b}$ & $\mathrm{T}$ \\
\hline 30 & Chow chow & 12 & 21 & Male & multicentric & V & $\mathrm{b}$ & $\mathrm{B}$ \\
\hline
\end{tabular}


abdominal volume (4\%). No dog showed cancer cachexia; however, 16 dogs (53\%) had a body condition score of 2 (out of 5), which is considered underweight.

The alterations in laboratory values and reports of paraneoplastic syndromes observed in this study are shown in Table 2. Anemia was frequently observed, as was leukocytosis, thrombocytopenia, lymphopenia, hyperglobulinemia and hypercalcemia.

Table 2. Occurrence of laboratory abnormalities and paraneoplastic syndromes in $\mathbf{3 0}$ dogs with lymphoma

\begin{tabular}{lccc}
\hline \multicolumn{1}{c}{ Type } & Reference value & Number of animals & $\%$ \\
\hline Anemia & Hematocrit $<37 \%$ & 17 & 57 \\
Leukocytosis & Leukocytes $>17000 / \mu \mathrm{L}$ & 12 & 40 \\
Leukopenia & Leukocytes $<6000 / \mu \mathrm{L}$ & 2 & 7 \\
Thrombocytopenia & Platelets $<200 \times 103 / \mu \mathrm{L}$ & 10 & 33 \\
Thrombocytosis & Platelets $>500 \times 103 / \mu \mathrm{L}$ & 1 & 3 \\
Lymphopenia & Lymphocytes $<1000 / \mu \mathrm{L}$ & 9 & 30 \\
Lymphocytosis & Lymphocytes $>4800 / \mu \mathrm{L}$ & 2 & 7 \\
Hyperglobulinemia & Globulin $>44 \mathrm{gL}$ & 6 & 20 \\
Hyperproteinemia & Total protein $>71 \mathrm{gL}$ & 5 & 17 \\
Gammopathy & Gama $>1.8 \mathrm{~g} / \mathrm{dL}$ & 2 & 7 \\
Hypercalcemia & Calcium $>11.3 \mathrm{mg} / \mathrm{dL}$ & 4 & 13
\end{tabular}

\section{DISCUSSION}

The results of this study demonstrated that the majority of dogs with lymphoma in Porto Alegre had the multicentric form with a B phenotype. These data are consistent with results of other studies worldwide. The multicentric form, reported to be the most common anatomical form of lymphoma in dogs and occurring in 68 to $91 \%$ of dogs with lymphoma (Sequeira et al. 1999, Cardoso et al. 2003, Ponce et al. 2010), occurred in $87 \%$ of cases, similar to another study perfomed in Brazil, were the multicentric form occurred in $93 \%$ of the dogs (Fighera et al. 2006). Some studies have demonstrated that the mediastinal form is the second most frequently anatomical form in dogs, occurring in 6 to $10 \%$ of the cases (Sequeira et al. 1999, Cardoso et al. 2003), but this form was not observed in the present study. The cutaneous form represented $7 \%$ of all lymphomas diagnosed in dogs in this study; other studies have found variability in the frequency of this type, with values ranging from $1.7 \%$ to $12.3 \%$ in other countries (Gavazza et al. 2008, Ponce et al. 2010) and in other Brazilian studies (Sequeira et al. 1999, Cardoso et al. 2003, Fighera et al. 2006). The intestinal and splenic forms occurred once each in this study and are considered uncommon in dogs (Gavazza et al. 2008). Ponce et al. (2010) reported an incidence of $1.8 \%$ of the splenic form and $1.5 \%$ of the intestinal form.

The B-cell lymphoma was the most common immunophenotype in dogs in Porto Alegre, occurring in $62 \%$ of the cases evaluated. There are few studies assessing immunohistochemistry of lymphomas in Brazil. Two studies showed a higher occurrence of $\mathrm{T}$ immunophenotypes, with prevalences of 53.5 to $60.2 \%$ (Moura 2000, Moreno \& Bracarense 2007). The findings of the present study are more similar to those observed in France (Ponce et al. 2010) and Austria (Arespacochaga et al. 2007), where $63.8 \%$ of cases were of the B-cell type, though other studies in Europe reported even higher frequencies (from 74 to $80 \%$ ) of the B-cell immunophenotypes (Fournel-Fleury et al. 1997, Vezzali et al. 2009). Therefore, more studies with larger numbers of dogs should be conducted in Brazil to evaluate the incidence and possible regional variations of T-cell lymphomas.

In this study, dogs were most frequently middle-age to older (mean age 9 years). It is known that lymphomas affect dogs of all ages, predominantly those of middle age (Teske 1994). Studies have documented mean ages ranging from 6.2 to 8.9 years in dogs with lymphoma (Dorn et al. 1967, Sequeira et al. 1999, Dobson et al. 2001). Age-specific incidence rates calculated in the USA included 1.5/100,000 in dogs less than one year old and more than 80/100,000 in dogs 10 years old (Dorn et al. 1967). Although no gender tendency is associated with lymphoma in dogs, males (63\%) were predominant in this study, equal to a study conducted in southern Brazil (Figueira et al. 2006) and similar with results from other countries where the proportion of males varied from $53 \%$ to $58 \%$ (MacEwen et al. 1987, Dobson et al. 2001).

Dobson et al. (2001) observed a mean weight of $31.6 \mathrm{~kg}$ $(\mathrm{SD}=14 \mathrm{~kg})$ in dogs with lymphoma; in this study, the mean weight of affected animals was $19.5 \mathrm{~kg}$, which reflects the occurrence of lymphoma in both small and large breeds. Some small breeds that frequently experience lymphoma include the Poodle and Scottish Terrier (MacEwen et al. 1987, Dobson et al. 2001), which were represented in this study. However, excluding the mixed breed animals, 59\% of the dogs in this study were large breed, including the most frequently diagnosed Boxer, Rottweiler and German Shepherd (Dobson et al. 2001, Pastor et al. 2009). Pastor et al. (2009) and Ponce et al. (2010) documented a significant overrepresentation of Boxers with T-cell lymphomas; however, the Boxer in this study had a B-cell lymphoma. Pastor et al. (2009) also reported that German Shepherds and Rottweilers are predisposed to B-cell lymphomas; our results seem to support this observation, as all dogs of these breeds had the B-cell phenotype.

Unlike the status of lymphoma in human medicine, clinical stages IV and $\mathrm{V}$ are the most frequently detected stages in dogs, occurring in 51.9 to $74.2 \%$ of all cases (MacEwen et al. 1987, Cardoso et al. 2003, Gavazza et al. 2008, Cápua et al. 2011). According to bone marrow evaluation, a technique that is fundamental to the correct clinical staging of lymphomas (Teske 1994), 63.3\% of the animals were classified as being in clinical stages IV or V in our study. In addition, $23.33 \%$ of the animals in this study were in stage $V$; in other studies, the percentages of animals in stage $\mathrm{V}$ were similar, ranging from 18 to 29\% (MacEwen et al. 1987, Cardoso et al. 2003), though one study reported a percentage of only 4.3\% (Dobson et al. 2001). Studies performed in the USA evaluating the sub-stage of dogs with lymphoma showed a high percentage of dogs in sub-stage "a" (Valerius et al. 1997, Chun et al. 2000, Garret et al. 2002). In Italy, Dobson et al. (2001) reported an incidence of $49 \%$ of animals in sub-stage "a" and $51 \%$ in stage "b". In our work, $17 \%$ of the animals were in sub-stage "a", and the majority (83\%) showed clinical signs compatible with sub-stage "b"; these findings are in accordance with the findings of Cápua et al. 
(2011) in Brazil, who found 33\% of subjects to be in sub-stage "a" and $67 \%$ in sub-stage "b". The higher incidence of symptomatic animals in Brazil may be related to the fact that owners may not observe enlarged lymph nodes in their animals as early as owners in other countries and may have less access to veterinary services.

The clinical signs associated with canine lymphoma are variable and depend on the location of the tumor. In the multicentric form, a generalized painless lymphadenopathy is the most consistent finding, associated or not with non-specific signs such as depression and emaciation (Teske 1994). Lymphadenopathy was frequently observed in this study (67\%), associated with non-specific signs such as prostration, decreased appetite, emaciation and anorexia. These findings are similar to those reported in other studies (Cardoso et al. 2004a, Gavazza et al. 2008, Fighera et al. 2006). However, a large number of patients also showed signs of respiratory distress, such as dyspnea and gagging, which are frequently detected in animals with the mediastinal form (Teske 1994) which was not observed in our study. Nevertheless, the multicentric form may lead to an enlargement of thoracic lymph nodes, that can cause a pleural effusion (Cardoso et al. 2004a). In addition, the increased size of the retropharyngeal and submandibular lymph nodes can cause gagging, as observed in this study.

Anemia was the most frequently encountered laboratory abnormality in this study, occurring in $57 \%$ of the animals. Others studies detected anemia in 32 to $48 \%$ of dogs with lymphoma (Cardoso et al. 2004b, Gavazza et al. 2008, Miller et al. 2009). The increased number of anemic patients in this study was most likely due to their more advanced clinical stage and sub-stage. Anemia detected in patients with lymphoma is generally consistent with a chronic disease, but can also be related to hemolysis or be of bone marrow origin (Vail \& Young 2007). Other frequent alterations observed in the CBC of dogs with lymphoma included leukocytosis (40\%), thrombocytopenia (33\%) and lymphopenia (30\%). Leukocytosis is often detected in dogs with lymphoma, reflecting the inflammatory condition related to the tumor (Cápua et al. 2011). Thrombocytopenia occurs in 15 to $56 \%$ of dogs with lymphoma and is related to the immune-mediated destruction and / or bone marrow involvement (Cardoso et al. 2004b, Cápua et al. 2011). Lymphopenia (30\%) was a common finding in this study and was encountered more often than lymphocytosis (7\%) and occurs due to sequestration of lymphocytes because of lymph stasis (Latimer \& Prasse 2003). Lymphocytosis has been observed in 20 to $22 \%$ of dogs with lymphoma (Cardoso et al. 2004b, Cápua et al. 2011), but in animals with leukemic lymphoma, the occurrence increases to $86 \%$ (Tasca et al. 2009). Although not a common finding in our study, atypical lymphocytes were detected in $17 \%$ of the cases, all of them with bone marrow involvement.

Along with changes in blood count, other frequent paraneoplastic syndromes observed in dogs with lymphoma include hypercalcemia and gammopathy (Morrison 1979, Vail \& Young 2007), both of which were detected in this study. Studies have reported hypercalcemia in 7 to $45 \%$ of dogs with lymphoma (Gavazza et al. 2008, Messinger et al.
2009 ) in similar proportions to those encountered in this study (13\%). According to Messinger et al. (2009), lymphoma is the main cause of increased concentrations of serum ionized calcium in dogs. Protein abnormalities were also frequently detected in this study. While hyperglobulinemia was common (20\%), the evaluation of the fractions with protein electrophoresis showed that only $7 \%$ of the animals had a gammopathy. Cardoso et al. (2004b) also reported $20 \%$ of cases with hyperglobulinemia; however, protein electrophoresis was not performed in their study. The excessive increase in production of immunoglobulin $G$ interferes with platelet function, causing coagulation disorders and a hyperviscosity syndrome, which can lead to neurological, cardiac and renal disorders (Fighera et al. 2002). However, no animal in this study showed clinical signs related to gammopathy.

According to Bergman (2007), cancer cachexia occurs frequently in human medicine, with an incidence of 40 to $90 \%$ in hospitalized patients. Although no animal presented with cachexia at the diagnosis of lymphoma in this study, $53 \%$ of the animals were malnourished. Few studies have evaluated cachexia and anorexia in dogs with lymphoma. A study performed in an oncology veterinary service reported that $4 \%$ of patients with cancer had cachexia and $15 \%$ had muscle loss (Michel et al. 2004). In Brazil, one study observed that $71 \%$ of dogs with lymphoma had experienced weight loss (Ramos et al. 2008), in similar proportions to those observed in our study. It is likely that this higher occurrence of malnutrition in dogs with lymphoma in Brazil is due to the delay in recognizing the disease by the owners; however, more studies evaluating this paraneoplastic syndrome in dogs with lymphoma must be performed to evaluate this condition and ascertain whether there is a correlation between the condition and the prognosis of the patient, as in human oncology.

\section{CONCLUSIONS}

The results of this study indicate that the epidemiological and clinical characteristics of dogs with lymphoma in the region of Porto Alegre, Brazil, are similar to those observed around the world. The multicentric form and the immunophenotype B predominated, and males and dogs of medium to large size were more frequently affected.

There was a higher incidence of dogs showing clinical signs, and the main laboratory abnormalities observed were changes in blood count, hypercalcemia and hyperproteinemia. Further studies must be conducted in Brazil to evaluate whether there is regional variation in immunophenotyping of dogs with lymphoma.

\section{REFERENCES}

Arespacochaga A.G., Schwendenwein I. \& Weissenböck H. 2007. Restrospective study of 82 cases of canine lymphoma in Austria based on the Working Formulation and immunophenotyping. J. Comp. Pathol. 136(2/3):186-192.

Bergman P.J. 2007. Paraneoplastic syndromes, p.77-90. In: Withrow S.J. \& Vail D.M. (Eds), Small Animal Clinical Oncology. $4^{\text {th }}$ ed. Saunders Elsevier, Saint Louis.

Cápua M.L.B., Coleta F.E.D., Canesin A.P.M.N., Godoy A.V., Calazans S.G., 
Miotto M.R., Daleck C.R. \& Santana A.E. 2011. Linfoma canino: clínica, hematologia e tratamento com o protocolo Madison-Wiscosin. Cienc. Rural 41(7):1245-1251.

Cardoso M.J.L., Machado L.H.A., Rocha N.S., Moutinho F.Q. \& Ciampolini P. 2003. Linfoma canino: revisão de cinquenta e quatro casos. Biosci. J. 19(3):131-142.

Cardoso M.J.L., Machado L.H.A., Moutinho F.Q. \& Padovani C.R. 2004a. Sinais clínicos do linfoma canino. Arch. Vet. Sci. 9(2):19-24.

Cardoso M.J.L., Machado L.H.A., Moutinho F.Q. \& Padovani C.R. 2004b. Linfoma canino: achados clínico-patológicos. Arch. Vet. Sci. 9(2):25-29.

Chun R., Garret L.D. \& Vail D.M. 2000. Evaluation of a high dose chemotherapy protocol with no maintenance therapy for dogs with lymphoma. J. Vet. Intern. Med. 14(2):120-124.

Dobson J.M., Blackwood L.B., McInnes E.F., Bostock D.E., Nicholls P., Hoather T.M. \& Tom B.D.M. 2001. Prognostic variables in canine multicentric lymphosarcoma. J. Small. Anim. Pract. 42(8):377-384.

Dorn C.R., Taylor D.O.N. \& Hibbard H.H. 1967. Epizootic characteristics of canine and feline leukemia and lymphoma. Am. J. Vet. Res. 28(125):9931001.

Fighera R.A., Souza T.M. \& Barros C.S.L. 2002. Linfossarcoma em cães. Ciência Rural 32(5):895-899.

Fighera R.A., Souza T.M., Rodrigues A. \& Barros C.S.L. 2006. Aspectos clinicopatológicos de 43 casos de linfoma em cães. MEDVEP - Revta Cient. Med. Vet. Pequenos Anim. Estim. 4(12):139-146.

Fighera R.A., Souza T.M., Silva M.C., Brum J.S., Graça D.L., Kommers G.D., Irigoyen L.F. \& Barros C.S.L. 2008. Causas de morte e razões para eutanásia de cães da mesorregião do centro ocidental rio-grandense (1965-2004). Pesq. Vet. Bras. 28(4):223-230.

Fisher S.G. \& Fisher R.I. 2004. The epidemiology of non-Hodgkin's lymphoma. Oncogene 23(38):6524-6534.

Fournel-Fleury C., Magnol J.P., Bricaire P., Marchal T., Chabanne L., Delverdier A., Bryon P.A. \& Felman P. 1997. Cytohistological and immunological classification of canine malignant lymphomas: comparison with human non-Hodgkin's lymphomas. J. Comp. Pathol. 117(1):35-59.

Garret L.D., Thamm D.H., Chun R., Dudley R. \& Vail D.M. 2002. Evaluation of a 6-month chemotherapy protocol with no maintence therapy for dogs with lymphoma. J. Vet. Intern. Med. 16(6):704-709.

Gavazza A., Lubas G., Valori E. \& Gugliucci B. 2008. Restrospective survey of malignant lymphoma cases in the dog: clinical, therapeutical and prognostic features. Vet. Res. Commun. 32(S1):S291-S293.

Greenlee P.G., Filippa D.A., Quimby F.W., Patnaik A.K., Calvano S.E., Matus R. E., Kimmel M., Hurvitz A.I. \& Leiberman P.H. 1990. Lymphomas in dogs: a morphologic, immunologic, and clinical study. Canc. 66(3):480-490.

Kronfeld D.S., Donoghue S. \& Glickman L.T. 1991. Body condition and energy intakes of dogs in a referral teaching hospital. J. Nutr. 121(S11):S157S158.

Latimer K.S. \& Prasse K.S. 2003. Leukocytes, p.46-79. In: Latimer K.S., Mahaffey E.A. \& Prasse K.W. (Eds), Veterinary Laboratory Medicine: clinical pathology. $4^{\text {th }}$ ed. Iowa State Press, Iowa.

MacEwen E.G., Hayes A.A., Matus R.E. \& Kurzman I. 1987. Evaluation of some prognostic factors for advanced multicentric lymphosarcoma in the dog: 147 cases (1978-1981). J. Am. Vet. Med. Assoc. 190(5):564-568.

Messinger J.S., Windham W.R. \& Ward C.R. 2009. Ionized hypercalcemia in dogs: a restrospective study of 109 cases (1998-2003). J. Vet. Intern. Med. 23(3):514-519.

Michel K.E., Sorenmo K. \& Shofer F.S. 2004. Evaluation of body condition and weigh loss in dogs presented to a veterinary oncology service. J. Vet. Intern. Med. 18(5):692-695.

Miller A.G., Morley P.S., Rao S., Avery A.C., Lana S.E. \& Olver C.S. 2009. Anemia is associated with decreased survival time in dogs with lymphoma. J. Vet. Intern. Med. 23(1):116-122.

Moreno K. \& Bracarense A.P.F.R.L. 2007. Linfoma canino de células T: aspectos epidemiológicos, clínicos e morfológicos de 38 casos. Braz. J. Vet. Anim. Sci. 44(S):103-110.

Morrison W.B. 1979. Paraneoplastic syndromes of the dog. J. Am. Vet. Med. Assoc. 175(6):559-561.

Moura V.M.B.D. 2000. Classificação citohistológica e imunofenotipagem dos linfomas caninos. Dissertação de Mestrado em Patologia Animal, Faculdade de Medicina Veterinária e Zootecnia, Universidade Estadual Paulista, Botucatu, SP. 107p.

Owen L.N. 1980. TNM Classification of Tumours in Domestic Animals. World Health Organization, Geneva. 53p.

Pastor M., Chalvet-Monfray K., Marchal T., Keck G., Magnol J.P., FournelFleury C. \& Ponce F. 2009. Genetic and environmental risk indicators in canine non-Hodgkin's lymphomas: breed association and geographic distribution of 608 cases diagnosed throughout France over 1 year. J. Vet. Intern. Med. 23(2):301-310.

Ponce F., Marchal T., Magnol J.P., Turinelli V., Ledieu D., Bonnefont C., Pastor M., Delignette M.L. \& Fournel-Fleury C. 2010. A morphological study of 608 cases of canine malignant lymphoma in France with a focus on comparative similarities between canine and human lymphoma morphology. Vet. Pathol. 47(3):414-433.

Ramos R.S., Machado L.H.A., Conceição L.C. \& Heckler M.C.T. 2008. Estudo da prevalência das principais síndromes paraneoplásicas de 14 cães com linfoma: relato de casos. Vet. Zootec. 15(3):38-39.

Sequeira J.L., Franco M., Bandarra E.P., Figueiredo L.M.A. \& Rocha N.S. 1999. Características anatomoclínicas dos linfomas caninos na região de Botucatu, São Paulo. Arq. Bras. Med. Vet. Zootec. 51(3):245-250.

Tasca S., Carli E., Caldin M., Menegazzo L., Furlanello T. \& Gallego L.S. 2009. Hematologic abnormalities and flow cytometric immunophenotyping results in dogs with hematopoietic neoplasia: 210 cases (2002-2006). Vet. Clin. Pathol. 38(1):2-12.

Teske E. 1994. Canine malignant lymphoma: a review and comparison with human non-Hodgkin's lymphoma. Vet. Quarterly 16(4):209-219.

Vail D.M. \& Young K.M. 2007. Hematopoietic tumors, p.699-733. In: Withrow S.J. \& Vail D.M. (Eds), Small Animal Clinical Oncology. $4^{\text {th }}$ ed. Saunders Elsevier, Saint Louis.

Valerius K.D., Ogilvie G.K., Mallinckrodt C.H. \& Getzy D.M. 1997. Doxorubicin alone or in combination with asparginase, followed by cyclophosphamide, vincristine, and prednisone for treatment of multicentric lymphoma in dogs: 121 cases (1987-1995). J. Am. Vet. Med. Assoc. 210(4):512-516.

Van Pelt R.W. \& Conner G.H. 1968. Clinicopathologic survey of malignant lymphoma in the dog. J. Am. Vet. Med. Assoc. 152(7):976-989.

Vezzali E., Parodi A.L., Marcato P.S. \& Bettini G. 2009. Histopathologic classification of 171 cases of canine and feline non-Hodgkin lymphoma according to WHO. Vet. Comp. Oncol. 8(1):38-49. 